\title{
PENGARUH PENGGUNAAN MACROMEDIA FLASH TERHADP HASIL BELAJARPADA POKOK PEMBAHASAN GEOMETRIDIMENSI TIGA
}

\author{
Hendri Raharjo, M.Kom \\ hendri.iainsnj@gmail.com \\ Tadris Matematika IAIN Syekh Nurjati Cirebon
}

\begin{abstract}
Abstrak
Keberhasilan suatu proses pembelajaran dapat diketahui dari tingkat penguasaan siswa terhadap materi yang diajarkan. Pelajaran matematika, khususnya materi geometri terasa sulit diberikan kepada peserta didik. Tujuan penelitian ini adalah untuk mengetahui pengaruh hasil belajar matematika siswa yang menggunakan macromediaflash dalam pembelajaran matematika. Populasi penelitian ini adalah siswa kelas VIII SMPN 2 Kapetakan Kabupaten Cirebon Tahun ajaran 2017/2018. Teknik sampling yang digunakan yaitu random sampling. Penelitian ini menggunakan pendekatan eksperimental dengan rancangan desain Randomized Control Group Only Design. Teknik analisis data yang digunakan menggunakan analisis deskriptif dengan uji hipotesis menggunakan uji Independent sampel t-test. Hasil penelitian menunjukkan rata-rata hasil belajar kelas eksperimen lebih baik daripada kelas kontrol. Respon siswa terhadap penggunaan macromedia flash pada pokok bahasan geometri dimensi tiga tergolong cukup baik. Terdapat pengaruh penggunaan macromedia flash terhadap hasil belajar matematika siswa. Penelitian selanjutnya dapat menggunakan macromedia flash untuk semua mata pelajaran sekolah dan alat yang diukur bisa lebih variatif.
\end{abstract}

Kata Kunci: Macromedia Flash, Hasil Belajar, Dimensi Tiga

\section{PENDAHULUAN}

Pendidikan adalah ruhnya peradaban manusia. Pendidikan yang berkembang dan maju akan membawa manusia pada perkembangan dan kemajuan pula. Setiap aspek kehidupan dikembangkan dalam dunia pendidikan.

Proses pendidikan itu sendiri diantarnya adalah kegiatan pembelajaran. Kegiatan pembelajaran yang kompleks dengan segala permasalahannya tentunya juga menuntut perkembangan dan keselarasan zaman sehingga perlu adanya penyesuaian. Penyesuaian dan perkembangan kegiatan pembelajaran itu diantaranya adalah hadirnya komputerisasi. Komputerisasi merupakan produk kemajuan ilmu dan teknologi.

Komputerisasi ini dipandang dapat mempermudah dan mengoptimalkan kegiatan pembelajaran. Kegiatan pembelajaran dengan model komputerisasi ini sebagai bagian dari variasi proses pembelajaran yang akan mengantarkan pelajar lebih kreatif. Oleh karena pembelajaran memerlukan alat pendukung, maka dari itu alat bantu media penyampaian pembelajaran sangat diperlukan sebagai transformasi pengetahuan baik secara konvensional di kelas maupun secara digital jarak jauh.

Penggunaan media dalam pembelajaran tidak dapat dipisahkan dan merupakan integrasi terhadap metode pembelajaran yang dipakai. Alat bantu atau bisa disebut media adalah unsur yang memiliki sifat kedinamisan dalam belajar. Media pembelajaran selalu menyesuaikan dari topik materi yang sedang diajarkan. Kedudukan alat bantu mempunyai peranan utama untuk membantu proses belajar, bahan ajar yang abstrak dapat dikonkretkan dan membuat suasana belajar tidak bosan.

Media atau alat bantu belajar dibuat dengan tujuan meningkatkan belajar mandiri, namun untuk hasil yang bagus maka pilihan media pembelajaran yang menarik, efektif dan interaktif adalah suatu permasalahan yang harus dicari solusinya. Media pembelajaran di era kemajuan teknologi saat ini sudah menjadi kebutuhan dalam proses pembelajaran. 
Hal diperlukan agar membangun kualitas manusia yang bukan hanya tergantung pas proses transfer pengetahuan secara verbal, baik yang dilakukan oleh sekolah maupun instansi pendidikan lainnya secara formal ataupun informal. Alat bantu yang dibuat harus dapat menyesuaikan subjek dan substansi dari mata pelajaran.

Saat ini mata pelajaran yang diajarkan masih cenderung menggunakan proses hafalan dengan buku panduan sebagai acuannya. Berbeda dengan aplikatif pembelajaran yang mengharuskan pembelajaran sebagai proses aplikatif topik atau praktek yang membutuhkan banyak informasi dan eksperimen. Dalam pembelajaran praktek, menggambarkan bahan ajar terkadang mengalami kesulitan yang disebabkan berbagai keterbatasan keterampilan, peralatan, bahan, hingga biaya. Dengan kata lain, tidak semua penyampaian pengetahuan dapat dengan cukup disampaikan secara verbal atau ceramah.

Tujuan penelitian ini adalah untuk mengetahui deskripsi hasil belajar matematika pada pokok bahasan geometri dimensi tiga di kelas eksperimen dan kontrol, mengetahui respon siswa terhadap penggunaan macromedia flash dalam pembelajaran matematika, dan untuk mengetahui pengaruh hubungan penggunaan macromedia flash terhadap hasil belajar matematika siswa pada pokok pembahasan geometri dimensi tiga.

\section{KAJIAN TORI}

Media adalah sebuah alat yang bertujuan untuk menyampaikan pesan (Ena. 2012: 2) media adalah saran informasi yang berasal dari informan yang diteruskan kepada sasaran penerima informasi tersebut. Menurut Azhar (2012: 12) media pembelajaran yaitu alat yang mempunyai fungsi sebagai penyampaian pesan atau materi pelajaran. Media pembelajaran sebagai aspek yang mendukung hasil belajar. Berdasarkan undang-undang republik 2003 Pasal 1 ayat 20: "Pembelajaran adalah kegiatan sosial yang dilakukan antara guru, siswa dan sumber belajar di lingkungan belajar tertentu".

Media pembelajaran mempunyai kegunaan untuk memberikan penjelasan informasi yang sudah disampaikan oleh sumber (guru). Media juga berfungsi sebagai bahan mandiri untuk melayani kebutuhan belajar siswa. Menurut Edgar dalam Prasetyo (2007:6) bah secara umum media memiliki fungsi memperjelas pesan supaya tidak verbalis, menyelesaikan masalah keterbatasan ruang waktu dan indera, meningkatkan minat belajar, interaksi secara langsung murid dengan sumber belajar, memungkinkan siswasecara mandiri yang disesuaikan oleh bakat dan kemampuan visual, auditori \& kinestetiknya, mengupayakan stimulus yang sama, mempersamakan pengalaman \& menimbulkan persepsi yang sama”.

Sedangkan berpendapat manfaat penggunaan media dalam pembelajaran adalah (Sigit: 2007: 7): Penyampaian materi dapat disamaratakan; Memperjelas materi pelajaran melalu proses pembelajaran yang menarik;Proses pembelajaran lebih menjadi interaktif; Efisiensi waktu dan tenaga; Meningkatkan kualitas hasil belajar siswa; Media berpeluang proses belajar dapat dilakukan secara fleksibel tanpa adanya keterbatasan tempat; Media dapat meningkatkan sikap positif terhadap materi dan kegiatan belajar; dan Memperbaiki peran guru menjadi lebih positif dan produktif.

Komputer sebagai produk dari kemajuan teknologi dapat dimafaatkan sebagai media pembelajaran yang interaktif. Dengan penerapan media pembelajaran diharapkan dapat meningkatkan daya pikir, perasaan, minat, serta perhatian siswa sehingga proses pembelajaran berlangsung dengan lancar. Saat ini komputer dapat dikatakan sebagai salah satu media pembelajaran. Dalam dunia pendidikan, komputer sudah banyak digunakan sebagai media pembelajaran.

Pada umumnya teknologi dapat mendukung proses atas standar ketercapaian tujuan pendidikan. Namun saat ini, komputer dan teknologi masih kurang dimanfaatkan secara optimal. Hal yang perlu diperhatikan adalah cara dan strategi kemanfaatan teknologi (komputer) dapat bermanfaat untuk kemajuan bidang pendidikan. Di lapangan,sistem penyajian topik materi pelajaran melalui komputer dilakukan dengan berbagai jenis seperti: simulasi-demokrasi, tutorial maupun hyperteks. 
Macromedia adalah perusahaan yang memproduksi perangkat lunak yang bergerak membuat grafis dan pengembangan web. Perusahaan ini hadir tahun 1992 dan mengalami perkembangan begitu maju pada tahun 1990-an dan 2000an. Desember 2005 Macromedia memiliki perusahaan yang bersaing yaitu Adobe Systems, Adobe saat ini masih menggunakan Macromedia pada beberapa program yang sudah dihasilkan. Macromedia hadir tahun 1992 melalui merger dan Authorware Inc dan MacroMind-Paracomp. Mulai di tahun 1990-an, produk laris macromedia yaitu membuat CD-ROM dan gerai center informasi masih, akan tetapi dengan meningkatnya ketenaran $w w w$ Macromedia menciptakan Shockwave, sebuah plugin Director bagi penjelajah web serta pada tahun 1996 menyatakan dua perusahaan berorientasi web, FutureWave Software (kemudian berganti nama menjadi Flash) dan iBand Software (pembuat aplikasi authoring HTML yang digunakan sebagai acuan membantu mengembangkan Dreamweaver).

Kemampuan menggambar objek seperti jam berbasis Flash atau animasi berekstensi gif, disebut bahwa Macromedia Flash merupakan pengembang perangkat lunak yang menciptakan objek dan gambar animasi yang keren. Ditambah oleh pembuatan gambar objek grafis vektor yang mumpuni, pemprograman ActionScript dan transisi dimana layer yang dinamis menciptakan produk ini lebih produktif dibandingan produk penciptaan animasi sejenis.

$$
\text { Geometri (geo-"bumi",-metron }
$$
"pengukuran") adalah bagian kajian matematika yang berkaitan dengan pertanyaan bentuk, ukuran, letak relatif tokoh, dan karakteristik ruang. Ahli ilmu ukur sering disebut dengan orang yang ahli matematika dalam bidang geometri.Geometri hadir secara independen di beberapa budaya awal dikatakan ilmu pengetahuan praktis mengenai ukuran panjang, luas, dan volume, berupa beberapa unsur dari ilmu matematika formal.Pada abad ke-3 SM geometri mulai aktif dalam bentuk aksiomatik oleh Euclid, yang didampingi oleh geometri Euclid, menjadi terkenal dan dijadikan pedoman dasar berabad-abad. Teknik cerdik yang dikembangkan oleh Archimedes bertujuan menghitung luas dan volume, untuk mengantisipasi pengerjaan kalkulus integral yang kekinian.

Subyek geometri selanjutnya dikembangkan oleh studi struktur intrinsik benda geometris yang bermula oleh Euler dan Gauss yang menghasilkan teori penciptaan topologi dan geometri diferensial. Dalam waktu Euclid tidak terdapat perbedaan yang signifikan antara ruang fisik dan geometris. Sejak awal abad ke-19 geometri non-Euclid, teori dasar ruang sudah terjaditransformasi radikal, dan berhasil memiliki pertanyaan: perbedaan ruang geometris yang paling sesuai dengan ruang fisik? Dengan perkembangan matematika formal dalam abad ke-20, juga 'ruang' (dan 'bidang', 'garis', 'titik') kehilangan isi intuitif, sehingga harus membedakan dimana ruang geometris, ruang fisik (di mana ' titik ',' ruang 'dan lain-lain masih mempunyai arti intuitif mereka) dan ruang abstrak.

\section{METODOLOGI PENELITIAN}

Penelitian ini bertempat di SMP Negeri 2 Kapetakan kabupaten Cirebon. Jenis Penelitian yang digunakan menggunakan pendekatan eksperimen dan model rancangan penelitian yang digunakan yaitu Randomized Control Group Only Design. Populasi yang digunakan adalah kelas VIII SMP Negeri 2 Kapetakan Kabupaten Cirebon Tahun ajaran 2017/2018. Dalam penelitian ini menggunakan metode penelitian eksperimen. Metode eksperimen merupakan metode penelitian dengan memberikan perlakukan khusus pada suatu kelompok penelitian. Metode eksperimen memberikan gambaran terhadap variabel yang diteliti menjadi lebih teliti. Adapun langkah-langkah penelitian yang dilakukan oleh peneliti adalah tahap persiapan, tahap pelaksanaan, tahap pengolahan data dan tahap kesimpulan.

Teknik pengambilan sampel secara acak dan didapatkan dua kelas untuk dijadikan sampel penelitian, yaitu kelas VIII A sebagai kelas eksperimen dan kelas VIII B sebagai kelas kontrol.Berdasarkan metode penelitian yang dipilih yaitu metode eksperimen, sehingga desain penelitian yang digunakan adalah 
eksperimental sederhana dengan subjek penelitian diambil secara random atau acak, dimana subjek penelitian hanya melakukan tes akhir saja. Berikut ini gambaran desai eksperimen sederhana menurut Rully dan Poppy.

$$
\mathrm{E}_{1}
$$

$\mathrm{K}_{1}$

$\begin{array}{ll}\mathrm{X} & \mathrm{Y}_{1} \\ \mathrm{O} & \mathrm{Y}_{2}\end{array}$

Keterangan:

$\mathrm{E}_{1} \quad$ : Kelompok Eksperimen

$\mathrm{K}_{1} \quad$ : Kelompok Kontrol

$\mathrm{X} \quad$ : Perlakuan khusus di kelas eksperimen

O : Tanpa perlakuan khusus

di kelas kontrol

$\mathrm{Y}_{1} \quad$ : Hasil Belajar Matematika kelas eksperimen

$\mathrm{Y}_{2} \quad$ : Hasil belajar matematika kelas kontrol

Teknik pengumpulan data melalui tes untuk mengetahui hasil tes belajar matematika dan angket untuk mengetahui respon penggunaan macromedia flash. Sedangkan teknik analisis data menggunakan uji statistik parametrik, salah satu diantaranya adalah statistik deskriptif, uji normalitas, uji homogenitas, dan uji hipotesis menggunakan uji Independent Samples t-test.

Selanjutnya untuk mengetahui pengaruh atau hubungan antar variabel yang sedang diteliti, maka penelitian ini difokuskan pada variabel yang hanya diteliti saja yaitu penggunaan macromedia flash terhadap hasil belajar matematika siswa. Pola hubungan antar variabel seperti berikut ini.

Keterangan:

$$
\mathrm{X} \rightarrow \mathrm{Y}
$$

$\mathrm{X} \quad$ : Penggunaan macromedia flash dalam pembelajaran matematika

$\rightarrow \quad$ : Pengaruh atau hubungan

Y : Hasil belajar matematika pokok pembahasan geometri dimensi tiga

\section{Hasil Penelitian}

Penelitian dilakukan dengan menggunakan dua kelas yaitu kelas eksperimen yang menggunakan macromedia flash dan kelas kontrol yang tidak menggunakan macromedia flash. Kedua kelas tersebut disebarkan soal matematika untuk mengetahui rata-rata hasil belajar matematika siswa. Hasil perhitungan tes matematika kedua kelas tersebut dapat dilihat melalui tabel di bawah ini:

Tabel 1

Hasil Tes Matematika Kelas Eksperimen dan Kontrol

\begin{tabular}{|l|l|l|}
\hline & Eksperimen & Kontrol \\
\hline $\mathrm{N}$ & 32 & 32 \\
\hline Range & 35,00 & 30,00 \\
\hline Minimum & 55,00 & 50,00 \\
\hline Maximum & 90,00 & 80,00 \\
\hline Mean & 80,1563 & 62,8125 \\
\hline Std. Deviation & 7,98026 & 9,15260 \\
\hline Variance & 63,684 & 83,770 \\
\hline
\end{tabular}

Dari hasil perolehan penyebaran tes matematika siswa terhadap penggunaan macromedia flash 8 dalam pembelajaran matematika di sekolah bahwa diketahui bahwa nilai rata-rata hasil tes matematika sebesar 80,15, standar deviasi sebesar 7,980, varian sebesar 63,684, nilai minimum sebesar 55, nilai maksimum 90 dan range sebesar 35 . Sedangkan hasil perolehan penyebaran tes matematika siswa yang berasal dari kelas kontrol bahwa diketahui nilai rata-rata hasil tes matematika sebesar 62,81, standar deviasi sebesar 9,152, varian sebesar 83,770, nilai minimum sebesar 50, nilai maksimum 80 dan range sebesar 30 .

Diagram berikut disajikan untuk mengetahui perolehan statistik kelas eksperimen dan kontrol dapat dilihat di bawah ini.

Diagram 1

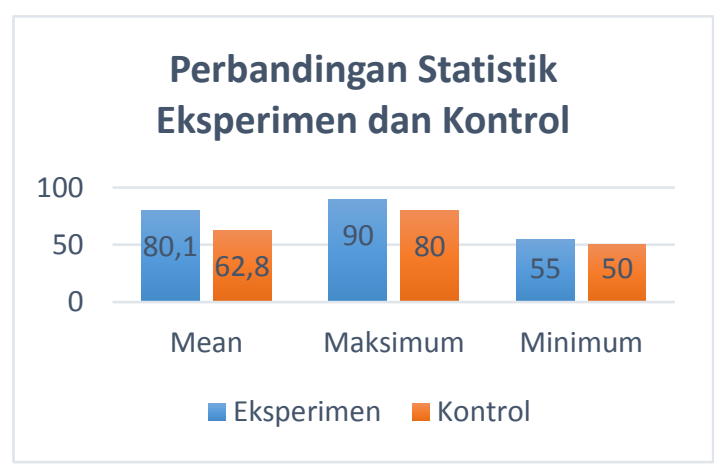

Perbandingan Statistik Kelas Eksperimen dan Kontrol 
Berdasarkan diagram 1 mengenai perbandingan statistik kelas eksperimen dan kontrol bahwa diketahui rata-rata tertinggi adalah kelas eksperimen dengan kata lain rata-rata kelas kontrol lebih rendah yaitu 80,1 dan 62,8. Nilai maksimum yang diperoleh di kelas eksperimen lebih tinggi daripada di kelas kontrol yaitu 90 dan 80. Nilai minimum yang diperoleh di kelas eksperimen lebih tinggi daripada di kelas kontrol yaitu 55 dan 50. Sehingga dari perolehan rata-rata, nilai maksimum dan nilai minimum kelas eksperimen yang menggunakan macromedia flash 8 dalam pembelajaran matematika dianggap lebih baik.

Data angket respon siswa terhadap penggunaan macromedia flash 8 ini hanya disebarkan kepada kelas eksperimen yaitu kelas yang diberikan perlakuan macromedia flash 8 dalam pembelajaran matematika di kelas. Dari penyebaran angket diperoleh respon sebanyak 32 siswa yang kemudian diolah dan dihitung untuk mengetahui keadaan data tersebut. hasil perhitungan deskripsi respon angket terhadap penggunaan macromedia flash 8dapat dilihat melalui tabel di bawah ini.

Tabel 2

Deskripsi Statistik Respon Siswa terhadap Macromedia Flash 8

\begin{tabular}{ll}
\hline Deskriptif Data & Angket \\
\hline Mean & 46 \\
Standard Error & 0,951442 \\
Median & 45 \\
Mode & 44 \\
Standard & \\
Deviation & 5,382169
\end{tabular}

\begin{tabular}{ll} 
Sample Variance & 28,96774 \\
Range & 26 \\
Minimum & 30 \\
Maximum & 56 \\
Count & 32 \\
\hline
\end{tabular}

Dari hasil perolehan penyebaran angket respon siswa terhadap penggunaan macromedia flash 8dalam pembelajaran matematika di sekolah bahwa diketahui bahwa nilai rata-rata respon siswa sebesar 46,75, standar deviasi sebesar 4,964, varian sebesar 24,645, nilai minimum sebesar 32, nilai maksimum 56 dan range sebesar 24. Sedangkan untuk mengetahui penyebaran skor respon siswa terhadap penggunaan macromedia flash 8 .

Dari peroleh data frekuensi tersebut dapat diketahui bahwa yang memperoleh skor 32 sebanyak 1 siswa, skor 38 sebanyak 1 siswa, skor 42 sebanyak 3 siswa, skor 43 sebanyak 2 siswa, skor 44 sebanyak 3 siswa, skor 45 sebanyak 2 siswa, skor 46 sebanyak 5 siswa, skor 47 sebanyak 1 siswa, skor 48 sebanyak 2 siswa, skor 49 sebanyak 4 siswa skor 51 sebanyak 2 siswa, skor 52 sebanyak 1 siswa, skor 53 sebanyak 3 siswa, skor 54 sebanyak 1 siswa, skor 56 sebanyak 1 siswa. Sehingga dapat diketahui bahwa frekuensi skor terbanyak adalah 46 sebanyak 5 siswa dan skor tertinggi 56 sebanyak 1 siswa.

Hasil data penelitian angket penggunaan macromedia flash 8yang disebarkan kepada 32 siswa telah dihitung berdasarkan indikator masing-masing pernyataan.

Tabel 3

Rekaptulasi Presentase Indikator Angket Macromedia Flash

\begin{tabular}{|l|l|}
\hline \multicolumn{1}{|c|}{ Indikator } & presetase \\
\hline Saya malas belajar matematika ketika menggunakan macromedia flash & $76 \%$ \\
\hline Saya tidak bisa atau kesulitan menjawab pertanyaan dari guru & $78 \%$ \\
\hline Saya tidak dapat fokus saat belajar menggunakan macromedia flash & $73 \%$ \\
\hline $\begin{array}{l}\text { Saya cenderung diam tidak menanggapi pertanyaan teman meskipun tahu } \\
\text { jawabannya }\end{array}$ & $62 \%$ \\
\hline $\begin{array}{l}\text { Saya tidak dapat mendeskripsikan materi dimensi tiga yang dijelaskan } \\
\text { menggunakan maacromedia flash }\end{array}$ & $74 \%$ \\
\hline Saya mampu menjawab pertanyaan yang diberikan guru & $67 \%$ \\
\hline
\end{tabular}




\begin{tabular}{|l|l|}
\hline \multicolumn{1}{|c|}{ Indikator } & presetase \\
\hline $\begin{array}{l}\text { Saya akan cenderung diam ketika guru bertanya saat pembelajaran menggunakan } \\
\text { macromedia flash }\end{array}$ & $70 \%$ \\
\hline $\begin{array}{l}\text { Saya merasa malu bertanya kepada guru dan teman ketika ada materi yang tidak } \\
\text { dipahami }\end{array}$ & $72 \%$ \\
\hline Saya dapat menyelesaikan tugas matematika dengan baik & $61 \%$ \\
\hline Saya kesulitan menyelesaikan tugas kelompok yang diberikan oleh guru & $76 \%$ \\
\hline Saya bisa menjawab pertanyaan guru saat belajar menggunakan macromedia flash & $58 \%$ \\
\hline $\begin{array}{l}\text { Saya lebih aktif bertanya kepada guru atau teman ketika ada materi matematika } \\
\text { yang kurang dipahami }\end{array}$ & $67 \%$ \\
\hline $\begin{array}{l}\text { Saya dapat mendeskripsikan materi dimensi tiga yang dijelaskan menggunakan } \\
\text { aaacromedia flash }\end{array}$ & $61 \%$ \\
\hline $\begin{array}{l}\text { Saya merasakan lebih semangat belajar matematika ketika menggunakan } \\
\text { macromedia flash }\end{array}$ & $63 \%$ \\
\hline Saya lebih fokus belajar matematika menggunakan media macromedia flash & $63 \%$ \\
\hline Saya akan menanggapi pertanyaan teman saya apabila saya mengerti & $63 \%$ \\
\hline $\begin{array}{l}\text { Saya lebih mudah memahami materi dimensi tiga ketika menggunakan macromedia } \\
\text { flash }\end{array}$ & $68 \%$ \\
\hline $\begin{array}{l}\text { Saya merasa kesulitan memahami materi dimensi tiga ketika menggunakan } \\
\text { macromedia flash }\end{array}$ & $80 \%$ \\
\hline $\begin{array}{l}\text { Pembelajaran menggunakan macromedia flash membuat materi konsep dimensi } \\
\text { tiga cepat dimengerti }\end{array}$ & $66 \%$ \\
\hline $\begin{array}{l}\text { Pembelajaran menggunakan macromedia flash membuat saya tidak mengerti } \\
\text { materi dimensi tiga }\end{array}$ & $80 \%$ \\
\hline
\end{tabular}

Berdasarkan tabel 3 dapat diketahui bahwa Indikator Saya malas belajar matematika ketika menggunakan macromedia flash sebesar $76 \%$. Indikator Saya tidak bisa atau kesulitan menjawab pertanyaan dari guru sebesar $78 \%$. Indikator Saya tidak dapat fokus saat belajar menggunakan macromedia flash sebesar 73\%. Indikator Saya cenderung diam tidak menanggapi pertanyaan teman meskipun tahu jawabannya sebesar $62 \%$. Indikator Saya tidak dapat mendeskripsikan materi dimensi tiga yang dijelaskan menggunakan macromedia flash sebesar 74\%. Indikator Saya mampu menjawab pertanyaan yang diberikan guru sebesar 67\%. Indikator Saya akan cenderung diam ketika guru bertanya saat pembelajaran menggunakan macromedia flash sebesar $70 \%$. Indikator Saya merasa malu bertanya kepada guru dan teman ketika ada materi yang tidak dipahami sebesar $72 \%$. Indikator Saya dapat menyelesaikan tugas matematika dengan baik sebesar $61 \%$. Indikator Saya kesulitan menyelesaikan tugas kelompok yang diberikan oleh guru sebesar $76 \%$. Indikator Saya bisa menjawab pertanyaan guru saat belajar menggunakan macromedia flash sebesar 58\%. Indikator
Saya lebih aktif bertanya kepada guru atau teman ketika ada materi matematika yang kurang dipahami sebesar $67 \%$. Indikator Saya dapat mendeskripsikan materi dimensi tiga yang dijelaskan menggunakan macromedia flash sebesar 61\%. Indikator Saya merasakan lebih semangat belajar matematika ketika menggunakan macromedia flash sebesar $63 \%$. Indikator Saya lebih fokus belajar matematika menggunakan media macromedia flash sebesar 63\%. Indikator Saya akan menanggapi pertanyaan teman saya apabila saya mengerti sebesar $63 \%$. Indikator Saya lebih mudah memahami materi dimensi tiga ketika menggunakan macromedia flash sebesar 68\%. Indikator Saya merasa kesulitan memahami materi dimensi tiga ketika menggunakan macromedia flash sebesar $80 \%$. Indikator Pembelajaran menggunakan macromedia flash membuat materi konsep dimensi tiga cepat dimengerti sebesar $66 \%$. Indikator Pembelajaran menggunakan macromedia flash membuat saya tidak mengerti materi dimensi tiga sebesar $80 \%$.

Penelitian ini menghasilkan dua jenis data, yaitu data respon penggunaan macromedia flash 8 dan data hasil tes matematika. Kedua data tersebut telah di 
uji normalitasnya menggunakan bantuan software SPSS. Hasil perhitungan uji normalitas data dapat dilihat melalui tabel di bawah ini.

Tabel 4

Uji Normalitas Data Penelitian

Tests of Normality

\begin{tabular}{|l|l|l|l|l|l|l|}
\hline \multirow{4}{*}{} & \multicolumn{3}{|l|}{$\begin{array}{l}\text { Kolmogorov- } \\
\text { Smirnova }\end{array}$} & \multicolumn{3}{l|}{ Shapiro-Wilk } \\
\cline { 2 - 7 } & $\begin{array}{l}\text { Statis } \\
\text { tic }\end{array}$ & $\begin{array}{l}\text { d } \\
\text { f }\end{array}$ & Sig & $\begin{array}{l}\text { Statis } \\
\text { tic }\end{array}$ & $\begin{array}{l}\text { d } \\
\text { f }\end{array}$ & $\begin{array}{l}\text { Si } \\
\text { g. }\end{array}$ \\
\hline Eksperi &, 134 & 3 &, 15 &, 896 & 3 &, 00 \\
men & 2 & 1 & 2 & 5 \\
Kontrol &, 128 & 3 &, 20 &, 919 & 3 &, 02 \\
& & 2 & $0^{*}$ &, 919 \\
\hline
\end{tabular}

Berdasarkan tabel 4 mengenai hasil perhitungan uji normalitas data, diketahui bahwa nilai signifikansi (sig.) kelas kontrol sebesar 0,200 dan signifikansi (sig.) sedangkan nilai sig kelas eksperimen sebesar 0,151.. Karena kedua data penelitian dari kelas eksperimen dan kontrol masing-masing lebih dari 0,05 atau dapat dilihat bahwa $0,200>0,05$ dan 0,151 $>0,05$ maka disimpulkan data berasal dari distribusi normal. Sehingga selanjutnya dapat dilakukan uji statistik parametrik.

Uji homogenitas dalam penelitian ini berasal dari data tes matematika kelas eksperimen yang dalam pembelajaran matematika menggunakan macromedia flash 8 dan data tes matematika yang berasal dari kelas kontrol. Dengan berbantuan software SPSS maka hasil perhitungan uji homogenitas adalah sebagai berikut:

Tabel 5

Uji homogenitas Data

\section{Test of Homogeneity of Variances}

Nilai

\begin{tabular}{|l|l|l|l|}
\hline $\begin{array}{l}\text { Levene } \\
\text { Statistic }\end{array}$ & df1 & df2 & Sig. \\
\hline 1,510 & 1 & 62 &, 224 \\
\hline
\end{tabular}

Data memiliki varian yang sama atau homogen jika nilai signifikansi (sig.) lebih dari 0,05 . Sedangkan data memiliki varian yang berbeda atau tidak homogen jika signifikansi (sig.) kurang dari 0,05.

Berdasarkan tabel 4.x mengenai hasil perhitungan uji homogenitas diketahui bahwa nilai signifikansi (sig.) sebesar 0,224. Karena 0,224 lebih besar dari 0,05 maka disimpulkan data penelitian bersifat homogen atau dengan kata lain data penelitian memiliki varian yang sama.

Uji hipotesis dalam penelitian ini menggunakan uji statistik Independent sampel t-test. Dengan menggunakan bantuan sofftware SPSS untuk menguji perbedaan hasil belajar matematika antara kelas eksperimen dan kontrol dan hasil perhitungan disajikan dalam tabel output sebagai berikut:

Tabel 6

Uji Independent T-Test

Independent Samples Test

\begin{tabular}{|c|c|c|c|c|c|c|c|c|c|c|}
\hline & \multicolumn{2}{|c|}{$\begin{array}{l}\text { Levene's } \\
\text { Test for } \\
\text { Equality } \\
\text { of } \\
\text { Variances }\end{array}$} & \multicolumn{7}{|c|}{ t-test for Equality of Means } \\
\hline & & \multirow[t]{2}{*}{$\mathrm{F}$} & \multirow[t]{2}{*}{$\begin{array}{l}\text { Sig } \\
\text {. }\end{array}$} & \multirow[t]{2}{*}{$\mathrm{t}$} & \multirow[t]{2}{*}{ df } & \multirow{2}{*}{$\begin{array}{l}\text { Sig. } \\
(2- \\
\text { tailed } \\
)\end{array}$} & \multirow[t]{2}{*}{$\begin{array}{l}\text { Mean } \\
\text { Differenc } \\
\text { e }\end{array}$} & \multirow{2}{*}{$\begin{array}{l}\text { Std. } \\
\text { Error } \\
\text { Differenc } \\
\text { e }\end{array}$} & \multicolumn{2}{|c|}{$\begin{array}{l}95 \% \text { Confidence } \\
\text { Interval of the } \\
\text { Difference }\end{array}$} \\
\hline & & & & & & & & & Lower & Upper \\
\hline $\begin{array}{l}\text { Nila } \\
\text { i }\end{array}$ & $\begin{array}{l}\text { Equal } \\
\text { variance } \\
\text { s } \\
\text { assume } \\
\text { d }\end{array}$ & $\begin{array}{l}1,51 \\
0\end{array}$ & $\begin{array}{l}, 22 \\
4\end{array}$ & $\begin{array}{l}8,08 \\
0\end{array}$ & 62 & ,000 & 17,34375 & 2,14662 & $\begin{array}{l}13,0527 \\
3\end{array}$ & $\begin{array}{l}21,6347 \\
7\end{array}$ \\
\hline
\end{tabular}




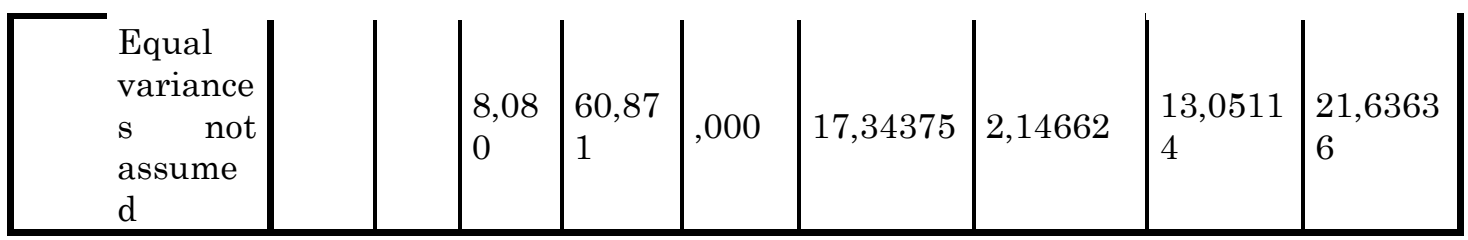

Berdasarkan hasil perhitungan uji perbedaan berbantuan software SPSS diperoleh output seperti tabel 6 di atas. Pengujian hipotesis yang dilakukan adalah ada perbedaan rerata hasil belajar tes matematika antara kelas eksperimen yang menggunakan macromedia flash 8 dan kelas kontrol yang tidak menggunakan macromedia flash.

Dari hasil perhitungan menggunakan software SPSS dengan diketahui data berdistribusi homogen maka perhitungan uji perbedaan berdasarkan baris equal variances assumed sehingga diperoleh $\mathrm{t}$ tabel sebesar 8,080 dan signifikansi sebesar 0,000. Dari df $62-2=60$ dan taraf signifikansi 0,05 diperoleh t tabel sebesar 2,000.

Uji hipotesis

Ha : ada perbedaan rerata kelas eksperimen dan kelas kontrol

Ho : tidak ada perbedaan rerata antara kelas eksperimen dan kelas kontrol

Apabila $\mathrm{t}$ hitung $>\mathrm{t}$ tabel maka $\mathrm{Ha}$ diterima, atau

Apabila signifikasi $<0,05$ maka $\mathrm{Ha}$ diterima.

Karena $\mathrm{t}$ hitung lebih besar dari $\mathrm{t}$ tabel atau 8,080 > 2,000 dan signifikansi kurang dari 0,05 atau $0,000<0,05$ sehingga dapat disimpulkan bahwa ada perbedaan antara kelas eksperimen dan kelas kontrol.

\section{Pembahasan}

Secara garis besar media pembelajaran macromedia flash 8 siswa diharapkan mampu belajar secara mandiri, menilai sejauh mana pemahaman terhadap materi. Dengan belajar sendiri ataupun dengan lebih menampilkan animasi yang ada. Maka, media ini bisa meningkatkan nilai siswa khususnya pada materi dimensi tiga yang memberikan contoh nyata secara visual sehingga mereka tidak susah payah membayangkan ataupun belajar bersama ilusi untuk mempelajari kedudukan, jarak, ataupun sudut antara titik, garis dan bidang. Hal yang terjadi saat penelitian berlangsung penggunaan macromedia flash 8 ini begitu menarik minat siswa untuk belajar dikarenakan materi lebih mudah dipahami. Mereka dapat melihat animasi berjalan sendiri dengan mengklik tombol play. Jadi, apa yang mereka bayangkan dapat dilihat secara visual.

Media pembelajaran ini dibuat sesuai dengan desain yang telah disusun. Desain media pembelajaran ini meliputi: menu utama, sub menu, template, layout, animasi, jenis dan ukuran huruf, dan sebagainya. Media pembelajaran ini dibuat menggunakan perangkat lunak macromedia flash 8. Tampilan awal halaman utama media pembelajaran diperlihatkan pada Gambar 1. Berikut.

Gambar 1. Halaman Utama Media Pembelajaran

Halaman utama memberikan gambaran tentang setiap pertemuan yang ada berisi materi bangun ruang dimensi tiga. Bagian pertama yang bisa digunakan

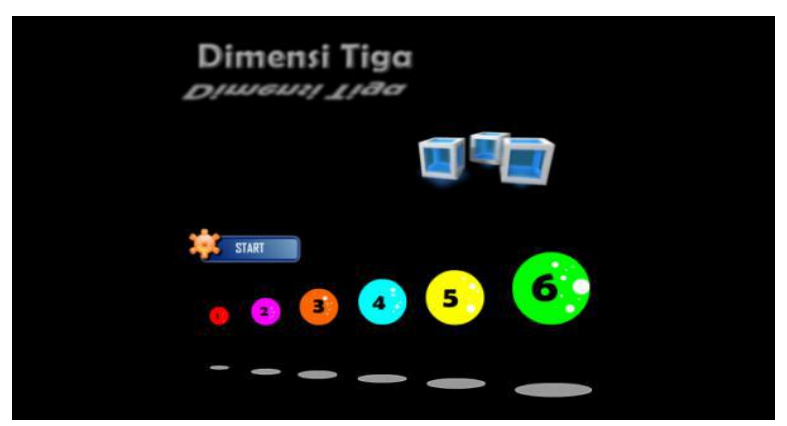

adalah menu peta konsep. Peta konsep adalah menu yang menampilkan titik, garis, bidang, kedudukan, jarak, dan sudut. Tampilannya dapat dilihat Gambar 2: 
Gambar 2. Tampilan Menu Peta Konsep

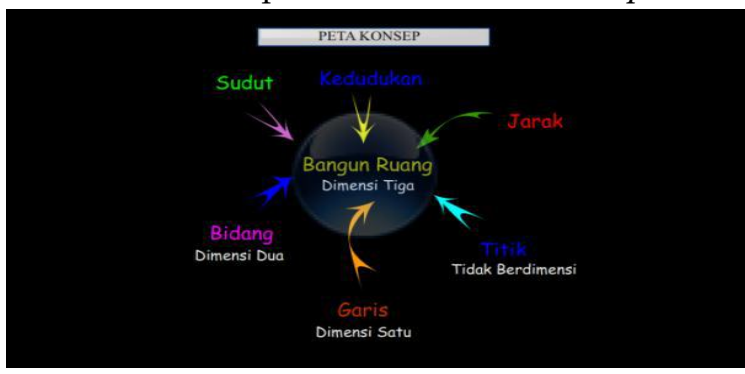

Kendala dan kesulitan yang ditemukan di awal penelitian adalah pada saat pemakaian laboratorium, karena jadwal pemakaian laboratorium di SMP N 2 Kapetakan perlu disesuaikan dengan mata pelajaran TIK. Fasilitas yang tersedia yaitu komputerkadang memiliki masalah dalam hal pengoperasian yang kadang tidak bisa dihidupkan serta komputer yang berjumlah terbatas mengakibatkan siswa belajar secara bergantian membuat proses belajarmengajar menjadi kurang efektif.

Selain itujuga penulis sedikit mengalami kesulitandalam mengatur siswa supaya tertib di dalam laboratorium. Berdasarkan kendala, permasalahan, danketerbatasan yang ada dapat dikemukakan beberapa solusi dan alternatif sebagai jalan keluar. Keterbatasan komputer di dalam ruangan laboratorium dapat ditindaklanjuti dengan menggunakan LCD dalam proses penelitian. Selain itu, siswa bisa membawa laptop bagi yang memiliki laptop, dan memberikan perangkat lunak macromediaflash 8 kepada siswa untuk mempelajari kembali materi di rumah mereka. Sehingga siswa yang berkemampuan rendah diberikan bimbingan dan motivasi kepada mereka agar selalu bertanya kepada guru maupun teman mengenai materi atau soal yang kurang dimengerti sehingga siswa tersebut selalu mau berusaha untuk menyelesaikan lembar latihan tepat waktu pada pertemuan selanjutnya.

Pembelajaran menggunakan perangkat lunak macromedia flash 8 lebih menarik dan membuat siswa memperhatikan serta aktif dalam proses belajar mengajar. Hal ini memperlihatkan siswa tertarik dan semakin bersemangat dalam belajar dengan menggunakan media ini. Siswa diberikan kesempatan untuk melakukan eksplorasi terhadap materi yang dipelajarinya sendiri. Selain itu materi yang dipelajari sendiri akan membuat materi melekat lebih lama pada siswa yang dapat membantu menunjang hasil belajar nantinya. Selain itu siswa juga dapat mengeksplorasi diri untuk lebih aktif dalam proses pembelajaran dengan bertanya kepada teman dan gurunya mengenai materi tersebut.

Dari penyebaran instrumen tes matematika topik geometri dimensi tiga yang diberikan kepada kelas eksperimen dan kontrol diperoleh data hasil belajar matematika siswa. Di kelas eksperimen memiliki rata-rata 80,15 sedangkan di kelas kontrol memiliki rata-rata. Nilai minimum yang dari kelas eksperimen sebesar 56 sedangkan di kelas kontrol sebesar 50. Nilai maksimum di kelas eksperimen sebesar 90 sedangkan di kelas kontrol sebesar 80. Standar deviasi di kelas kontrol sebesar 9,15 sedangkan di kelas eksperimen sebesar 7,98. Dan varian atau keberagaman nilai tes matematika di kelas eksperimen sebesar 63,68 sedangkan di kelas kontrol sebesar 83,77.

Dari penjelasan mengenai statistik deskriptif tes matematika kelas eksperimen dan kontrol diketahui bahwa rata-rata nilai tes matematika di kelas eksperimen lebih tinggi daripada kelas kontrol. Hal demikian dalam penelitian ini disebabkan salah satu faktornya adalah penggunaan macromedia flash 8 dalam pembelajaran matematika. Kelas eksperimen yang menggunakan macromedia flash 8lebih besar hasil tes matematikanya daripada kelas kontrol yang menggunakan pembelajaran tanpa macromedia flash 8. Begitu pula dengan nilai maksimum tes matematika di kelas eksperimen lebih tinggi daripada nilai maksimum tes matematika yang ada di kelas kontrol. Keberagaman jawaban siswa dari tes matematika di kelas kontrol lebih besar daripada kelas eksperimen yang menandakan keberagaman jawaban dari masing-masing soal dan masing-masing siswa cenderung banyak perbedaan.

Pembelajaran matematika menggunakan macromedia flash 8 yang dilaksanakan di kelas VIII A SMP Negeri 2 Kapetakan memiliki hasil belajar matematika pada topik geometri dimensi tiga lebih baik daripada kelas yang tidak menggunakan macromedia flash 8 dalam pembelajaran matematika. Hal ini selaras dengan hasil deskripsi statistik dari data 
penyebaran instrumen tes matematika topik geometri dimensi tiga.

Kendala dan kesulitan yang ditemukan di awal penelitian adalah pada saat pemakaian laboratorium, karena jadwal pemakaian labor di SMP Sultan Agung Sumber perlu disesuaikan dengan mata pelajaran TIK. Fasilitas yang tersedia yaitu komputer yang memiliki masalah dalam hal pengoperasianserta komputer yang berjumlah terbatas mengakibatkan siswa belajar secara bergantian membuat proses belajar mengajar menjadi kurang efektif. Selain itu, juga dialami kesulitan dalam mengatur siswa supaya tertib di dalam laboratorium. Berdasarkan kendala, permasalahan, dan keterbatasan yang ada dapat dikemukakan beberapa solusi dan alternatif sebagai jalan keluar. Keterbatasan komputer di dalam ruangan labor dapat ditindaklanjuti dengan menggunakan LCD dalam proses penelitian. Selain itu, siswa bisa membawa laptop bagi yang memiliki laptop, dan memberikan perangkat lunak macromedia flash 8 kepada siswa untuk mempelajari kembali materi di rumah mereka. Siswa yang berkemampuan rendah diberikan bimbingan dan motivasi kepada mereka agar selalu bertanya kepada guru maupun teman mengenai materi atau soal yang kurang dimengerti sehingga siswa tersebut selalu mau berusaha untuk menyelesaikanlembar latihan tepat waktu pada pertemuan selanjutnya. Usaha yang dilakukan agarwaktu yang tersedia cukup, maka penulis mempergunakan waktu seefektif mungkin agar setiap pertemuan tercapai sesuai dengan yang diharapkan.

$$
\text { Untuk mengetahui deskripsi }
$$

respon siswa terhadap penggunaan macromedia flash 8 dalam pembelajaran matematika di kelas eksperimen maka disebarkan angket respon kepada 32 responden yang berasal dari kelas eksperimen. Angket yang disediakan terdiri dari 20 pernyataan dimana masingmasing pernyataan memiliki tujuan untuk mengetahui respon siswa terhadap penggunaan macromedia flash 8 .

Berdasarkan hasil perhitungan angket penggunaan macromedia flash 8 diketahui bahwa rata-rata skor angket sebesar 46 , skor minimum sebesar 30 , skor maksimum sebesar 56. Rata-rata sebesar 46 menunjukkan gambaran secara umum di dalam kelas eksperimen memberikan respon sebesar 46. Jika di bandingkan dengan rata-rata idealnya sebesar 80 maka 46 dapat dimaksudnya cukup baik respon siswa terhadap penggunaan macromedia flash 8. Standar deviasi sebesar 5,382 menunjukkan bahwa peluang penyimpangan skor setiap responden terhadap rata-rata dalam satu kelas eksperimen, semakin kecil standar deviasi maka skor rata-rata angket setiap siswa mendekati rata-rata skor angket di dalam kelas eksperimen. Hal ini didukung dengan skor modus sebesar 44 yang artinya mendekati nilai rata-rata angket satu kelas eksperimen. Varian atau keberagaman respon angket diketahui sebesar 28,967 menunjukkan bahwa keberagaman jawaban respon siswa terhadap penggunaan macromedia flash 8 dalam pembelajaran matematika.

Data yang berasal dari tes di kelas eksperimen dan kontrol kemudian dilakukan uji normalitas data. Perhitungan uji normalitas data dihasil nilai signifikansi untuk data kelas eksperimen sebesar 0,151 dan nilai signifikansi kelas kontrol sebar 0,200. Oleh karena nilai signifikansi kedua sampel lebih dari 0,05 maka dapat disimpulkan data penelitian berdistribusi normal. Kemudian uji homogenitas kedua sampel menggunakan software SPSS dihasilkan output nilai signifikansi sebesar 0,224. Karena 0,224 lebih dari 0,05 maka dapat disimpulkan data memiliki varian yang sama. Berdasarkan uji normalitas dan uji homogenitas yang menghasilkan kedua uji tersebut lebih dari 0,05 maka selanjutnya dapat dilakukan uji parametrik untuk menguji hipotesis dalam penelitian.

Berdasarkan perhitungan independent samples t-test menggunakan software SPSS diperoleh bahwa nilai signifikansi sebesar 0,000 dan t hitung sebesar 8,080. Diketahui $t$ tabel dengan taraf alfa 0,05 dan jumlah sampel 62 maka diperoleh $\mathrm{t}$ tabel sebesar 2,000. Karena hasil nilai signifikansi kurang dari alfa atau $0,000<0,05$ dan t hitung lebih besar dari t tabel atau 8,080 $>2,000$. Maka dapat disimpulkan bahwa terdapat perbedaan antara siswa yang menggunakan macromedia flash 8 dalam pembelajaran matematika dengan yang tidak menggunakan macromedia flash 8

\section{Simpulan}

Hasil tes matematika pada pokok bahasan geometri dimensi tiga yang 
dilakukan di kelas eksperimen memperoleh nilai rata-rata sebesar 80,1 dengan nilai minimum 5 dan maksimum 90. Sedangkan hasil tes matematika yang dilakukan di kelas kontrol memperoleh nilai rata-rata sebesar 62,8 dengan nilai minimum sebesar 50 dan nilai maksimum sebesar 80 .

Angket respon siswa terhadap penggunaan macromedia flash dalam pembelajaran matematika memiliki hasil rata-rata dari skor total angket sebesar 46 dengan skor minimum sebesar 30 dan skor maksimum 56 dari skor ideal 80. Sedangkan dari salah satu indikator angket diketahui persentase indikator siswa merasa tidak mampu dalam menggunakan macromedia flash 80

Berdasarkan uji Independent samples t-test menggunakan SPSS diketahui bahwa nilai output signifikansi sebesar 0,000 dan thitung sebesar 8,080. Karena signifikansi kurang dari alfa atau 0,000 kurang dari 0,05 dan thitung lebih besar dari ttabel atau 8,080 > 2,000. Sehingga dapat disimpulkan bahwa terdapat perbedaan rata-rata hasil belajar matematika siswa pada pokok pembahasan geometri dimensi tiga antara yang menggunakan macromedia flash dan tidak menggunakan macromedia flash dalam pembelajaran matematika.

\section{Saran}

Macromedia flash merupakan salah satu media pembelajaran yang dapat digunakan dalam pembelajaran matematika. Macromedia flash dapat memberikan visualisasi matematika sehingga siswa dapat memahami konsep matematika lebih baik lagi. Di sisi lain macromedia flash dapat menumbuhkan rasa senang siswa terhadap pembelajaran matematika karena materi disajikan dalam bentuk animasi visual serta dilengkapi dengan suara. Oleh sebab itu, guru dapat menerapkan pembelajaran matematika menggunakan macromedia flash agar siswa lebih cepat memahami materi konsep matematika dan juga membuat pembelajaran tidak jenuh bagi para siswa.

Penelitian ini juga dilaksanakan untuk mengetahui pengaruh penggunaan macromedia flash terhadap hasil belajar matematika siswa. Sasaran yang dapat dilakukan oleh peneliti selanjutnya adalah menggunakan macromedia flash tidak hanya dalam pelajaran matematika dan pokok bahasan geometri dimensi tiga. Dengan kata lain, peneliti selanjutnya dapat mengembangkan sesuai dengan kondisi dan kebutuhan siswa tergantung tempat masing-masing. Peneliti selanjutnya juga dapat mengukur pengaruh penggunaan macromedia flash tidak hanya terhadap hasil belajar matematika saja, namun dapat dicari menggunakan variabel yang lainnya.

\section{DAFTAR PUSTAKA}

Alami, Fikri. 2005. Pembuatan Media Pembelajaran Dengan Macromedia FlashMVIII 2004. Lmpung: Universitas Lampung.

Anderson, Ronald H. 1987. Pemilihan dan Pengembangan Media untuk Pembelajaran. Jakarta: Rajawali Pers.

Arsyad, Azhar. 2002. Media Pembelajaran. Jakarta: PT Raja Grafindo Persada.

Djamarah, Syaiful Bahri. 2002. Psikologi Belajar. Jakarta: Rineka Cipta.

Hamalik, Umar. 2005. Psikologi Belajar dan Mengajar. Bandung: Sinar Baru.

Masykur. Mathematical Intelegence Cara Cerdas Melatih otak dan MenanggulangiKesulitan Brlajar. Yogyakarta: ArRuzzmedia

Munadi, Yudhi . 2008. Media Pembelajaran, Sebuah Pendekatan Baru.Jakarta: Gaung Persada Press.

Sucipto, Endar dkk. 2004. Matematika SMP untuk Kelas VIII. Jakarta: Erlangga

Sudijono, Anas. 1987. Pengantar Statistik Pendidikan. Jakarta: Rajawali Press. Sugiyono. 2009. Metode Penelitian Pendidikan Pendekatan Kuantitatif, Kualitatif, dan R\&D.Bandung: Alfabeta. 
$20 \begin{aligned} & \text { EduMa Vol. } 6 \text { No. } 2 \text { Desember } 2017 \\ & \text { ISSN 2086 - 3918 }\end{aligned}$

Suherman, Erman. 2001. Strategi Pembelajaran Kontemporer. Matematika Bandung: JICAUPIO

Sumardyono. 2004. Karakteristik Matematika dan Implikasinya terhadap

PembelajaranMatematika.

Yogyakarta: PPPG Matematika Sumaryanta. 2008. Matematika Apa dan Bagaimana (Handout). Yogyakarta:UIN Sunan Kalijaga: Program Studi Pendidikan Matematika.

Suparni. 2009. Perencanaan Pembelajaran Matematika (Handout). Yogyakarta: UIN Sunan Kalijaga: Program Studi Pendidikan Matematika.

Surya, Mohamad. 2004. Psikologi Pembelajaran dan Pengajaran. Bandung: Pustaka BaniQuraisy
Suryadi, Ace.Reformasi Sistem Pembelajaran (artikel)

Undang-undang Republik Indonesia Nomor 20 Tahun 2003 Tentang Sistem

Pendidikan Nasional: Jakarta, 2003.

USMPn, Basyiruddin, dkk.2002. Media Pembelajaran.Jakarta: Ciputat Press

Wirosari, Renati Winong, dkk. 2008. Adobe Flash CS3 Untuk Pemula.Yogyakarta:ANDI

Website:

http://id.wikipedia.org/wiki/Geometri

(diunduh pada tanggal 28 November 2013) http://matematika-

hebat.blogspot.com/2013/04/bangun-ruangdimensi-tiga.html (diunduh pada tanggal 28 November 2013)

http://ghose-

smkitpesat.blogspot.com/2012/02/dimensitiga-bangun-ruang.html (diunduh pada tanggal 28 November 2013) 